\title{
Impact of Using Digital Tools in High School Mathematics: A Case Study in North Macedonia
}

\author{
Aybeyan Selimi ${ }^{1, *}$, Muzafer Saracevic ${ }^{2}$, Arafat Useini ${ }^{3}$ \\ ${ }^{1}$ Faculty of Informatics, International Vision University, Gostivar, North Macedonia \\ ${ }^{2}$ Department of Computer Science, International University of Novi Pazar, Serbia \\ ${ }^{3}$ Faculty of Social Sciences, International Vision University, Gostivar, North Macedonia
}

Received May 11, 2020; Revised June 23, 2020; Accepted July 20, 2020

Copyright $\odot 2020$ by authors, all rights reserved. Authors agree that this article remains permanently open access under the terms of the Creative Commons Attribution License 4.0 International License

\begin{abstract}
This paper aims to examine the impact of digital tools in mathematics and the readiness of teachers and students applying these interactive tools in teaching. The data used in the research are obtained from the test results of 526 students, in five secondary schools in North Macedonia. The students in this research, are divided into two groups: mainly as a control group and an experimental group. The control group is the group of students who do not have access to the interactive tools at home and who use interactive tools only once a week in the school while the group of students in the experimental group have access to them and have the opportunity to use these interactive applications every day. The students in the control group and the experimental group were selected from the same year and the gender equality of the groups was taken into account. To further understand the relationship between teaching with digital tools and learning after testing was surveyed the participants. The results in our research suggest that interactive teaching tools have a positive impact on the teaching process and increase students' knowledge.
\end{abstract}

Keywords Interactive Teaching Tools, E-learning, Teaching, High School Mathematics and Knowledge

\section{Introduction}

One of the most important characteristics that distinguish human beings from other living creatures is his cognitive capacity of learning and teaching. Since the early ages, the experiences of the oldest have been transferred to the younger generation. Along with the development of society, a more successful organization teaching process should be required, also the acquisition of new knowledge and skills from younger generations.
Today, education is reflected as a change in any individual behavior and performs a process that aims at training well-educated and emancipated people. In education, students acquire the knowledge as well the skills that they are able to use them for further improvement. Teaching as the most significant part of education has two objectives which are classified - as general and specific objectives (Woolfolk, 2016). General objectives are characterized by practical upbringing and educational indicators. There is a mutual synthesis between these characteristics, but there are some differences.

The student enters the educational process with their own experience which has acquired in the family or own environment. As a person, the student is part of the group within the class but also is an individual in the learning process (Reynolds \& Miller, 2003).

Interactive education is an approach based on the principle of "active learning". This is also called "education without borders".

Learning is an individual process or activity. So, in order for the person to learn new knowledge he needs the experience to transfer from someone, i.e., he must communicate with a stimulator around him (Glenda, 1996). This stimulator in education activity is the "teacher". For this reason, it is necessary to develop a student's sense of responsibility and they must encourage them to participate actively in the learning process from beginning to end.

In (Rao \& DiCarlo, 2001) is shown that students learn better and faster when they participate actively in the teaching and they remember easily the facts and enjoy learning. On the other hand, students who are passive and uninterested namely forget quickly what they learned, and as a result, they are suppressed in class and they don't show an interest or a desire toward learning.

In the interactive learning, students aren't passive recipients of information, they are individuals who learn and shape their lives. Instead of being passive listeners, 
they read, write, speak, are in relationships with each other, apply the knowledge in everyday life, and solve problems. Active learning increases the motivation and self-esteem of students (Kimberly, 2002).

The educational process provides two activities. The first "learning" and the second is "teaching". These are the joint activities of students and teachers who are closely related to each other (Piaget, 1972). The concept of learning is one of the important points in the teaching process. Students' interest and dignity are significant in a learning activity, so it is essential for the development of independent learning. Here it is important to note that the student must be a guide of himself. Also, due to the aforementioned reasons, the teacher should be a good guide and a facilitator in education.

The constant progress in science and technology, causes a rapid change, also development in society. This, in turn, increases several behaviors that modern individuals need to learn. In this context, it is expected that the individuals will learn more about how to use the information than to remember or memorize.

Memorization and recognition are in the lowest level of learning as well as the reasoning and the application are at the highest level (Selimi, Saracevic \& Rushiti, 2018). Learning new skills imply a student can fully learn some skills, turn it into a knowledge that may be applied practically. Learning can only take place with the active participation of students. None, including the teacher, can force an individual to learn if he/she doesn't want to do so. The teacher is only a guide, that systematizes the steps and helps in the education process. Learning is not like physical growth. It does not require food; it is a set of activities that require intellectual abilities.

\section{Interactive Tools in Mathematics Teaching}

The development of modern technology progress enabled the use of new methods and principles in education. However, the new principles in the education process have been established for students to keep up with digital tools. These principles were given by Richard E. Mayer under three main topics (Mayer, 2009). Interactive content includes access to various information, whether video and audio materials, presentations or multimedia catalogs, in a word, all contents are displayed in a modern and their attractive ways of use. In mathematics teaching, Digital Videos represent a significant aspect in communication. Creating videos provide a different, and perhaps more interesting experience to help students communicate and better understand the math problems (Niess \& Walker, 2010). Platforms that are completed/realized with interactive content provide the possibility of learning at home without a teacher's presence (Saracevic, 2012). Such a platform must be with errors and meanings as small as possible that a student will be able to learn not to misinterpret the content. In (Hoyles \& Noss, 2003) have revealed that using digital tools shape learning. Thus working out with the digital technologies, show prospect in assisting this endeavor. The research (Monaghan \& Trouche, 2016) indicated a link between the mathematics teachers and the digital tools and it determined that students and teachers have opportunities using a multitude of digital tools that have the potential to answer complex mathematical questions and representations of mathematical objects and processes. In addition to geometry, digital tools, are also being used in teaching algebra. The digital tool's application in algebra is presented at work (Bokhove \& Drijvers, 2010). It is concluded that teaching with digital tools scores better results in the learning of concepts of algebra. The paper (Holmes, 2009) results indicated that teachers wanted to include interactive tools in teaching in varying degrees. Also, it was determined that the visual nature of digital technology motivates teachers to create activities for the understanding of abstract concepts. The study paper which was done by (Lin, Chen \& Liu, 2017) had shown that students agreed with digital learning in the subject matter. In particular, increasing learning time with digital tools relatively increases students to better and more successful learning performance. Thus, this research provides us with digital tools to help the teachers make better use of teaching strategies, also to create more achievable learning opportunities for students' interactive learning.

In addition, when he needs help to understand a certain matter, the computer "has got to be ready" to provide us with the required assistance. This kind of teaching where the digital tools play the role of a teacher is represented in the world. The advantages of using digital tools in teaching are multiplied, and interactivity and individual attention could be emphasized as the main ones (Vilotijević, 1999). The first advantage is that the digital tools allow each student to play an active role in the learning process, as opposed to the passive role of the book. The student is no longer an observer but an active participant in the learning process.

Another advantage relates us to the fact that teachers need to know that students are different, i.e. they all do not have the same knowledge and do not learn in the same way. However, many of our conventional educational approaches use rigid procedures for all students and do not allow them that these differences to be taken into account. The advantage of computers is that good software can individualize the teaching environment (Djukic, 1995).

All students do not learn at the same speed, i.e. each one needs different time allocations to go through the material. The computer also allows them to do so. The animation is the rapid display of sequences of $2 \mathrm{D}$ or $3 \mathrm{D}$ 
images or the position of the model set up to create an illusion of motion. This is the optical illusion of motion due to the phenomena of the persistence of vision and this can be made and displayed in different ways (Weiss, Knowlton \& Morrison, 2002).

The most commonly used methods of displaying are animations, pictures or videos. Computer Simulation is a computer-generated experiment. A key part of any Computer Simulation is a model that includes sizes whose values are unpredictable and therefore caused by the appropriate population (Atkinson, 2005). The model is most often represented by the use of a computer program, and the program actually causes random variables, executes model calculations, and reports the outcome, usually in the form of one or more numeric values.

In the contemporary teaching, we encounter to a multitude of different multimedia content that contributes to the quality of teaching, increasing motivation, progressive realization of subjects and better progression of individuals according to their intellectual abilities (Saracevic, Milosevic \& Masovic, 2012). Using the information and communication technologies, especially tools and technologies in electronic learning, participants will be able to expand, thus apply their already acquired knowledge, because modern teaching approaches aim in applying to have acquired theoretical knowledge in practice (Namestovski, 2008). Interactive teaching content is one special type of teaching using computers which are applicable in all disciplines, especially in the natural and technical sciences where there is a real need for visualization of the processes (Popović, 2010).

The most popular tools used to create applets for the teaching of mathematics are (Saracevic, Milosevic \& Masovic, 2012):

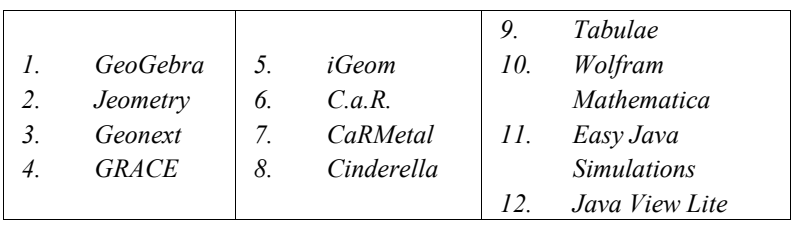

Geogebra is a tool, that due to the possibility of the dynamic display and interactivity of mathematical objects in teaching, it is used for explaining, researching and modeling mathematical concepts and their interrelations (Markus \& Hohenwarter, 2009). GeoGebra is a program for dynamic mathematics that links geometry, algebra, and mathematical analysis. It is developed for teaching and learning mathematics at schools. GeoGebra has three different concepts of mathematical objects - graphical representation, algebraic (numerical) display, and tabular display. It is possible to display the mathematical objects in three different forms by using them.

Unlike the paper sketch, which represents a static model, in Geogebra, it is possible to change certain parameters in the graphics window. In the process of constructing mathematical objects, certain parameters are defined there that needs to be applicable on the screen. This is enabled using the slider. The dynamism of the Geogebra program is particularly suitable for observation and visualization of certain mathematical objects dependencies on certain parameters. For example, when dealing with the dependence of the linear function $y=m x+n$ from the parameters $m$ and $n$, when drawing the function graphs in the Geogebra program, the parameters $m$ and $n$ can be defined to be variable in the image by the slider. Thus, the student will be able to monitor the change of appearance of the graphic of the function depending on the parameters mentioned and to be encouraged to perform independently to the conclusions.

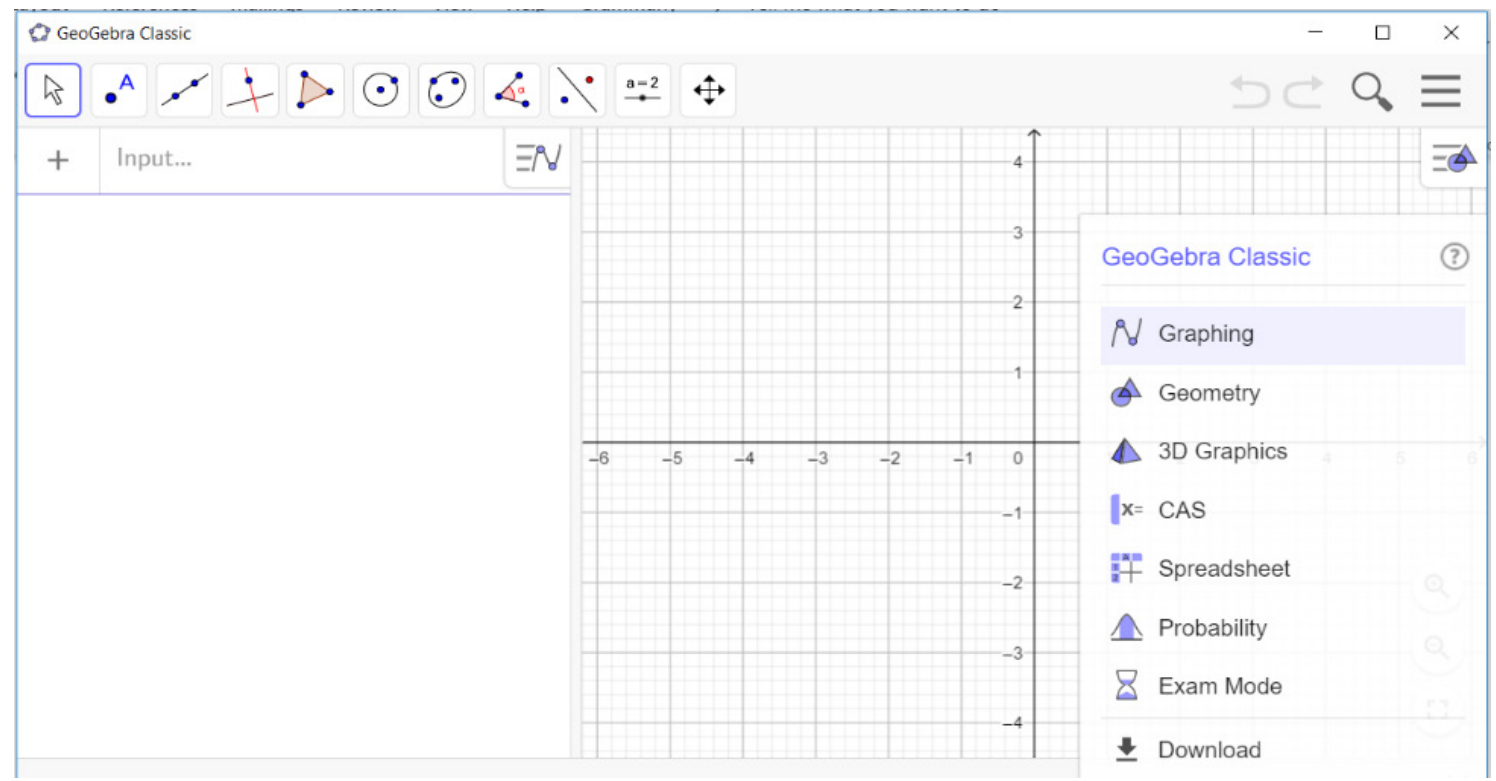

Figure 1. GeoGebra package environment 


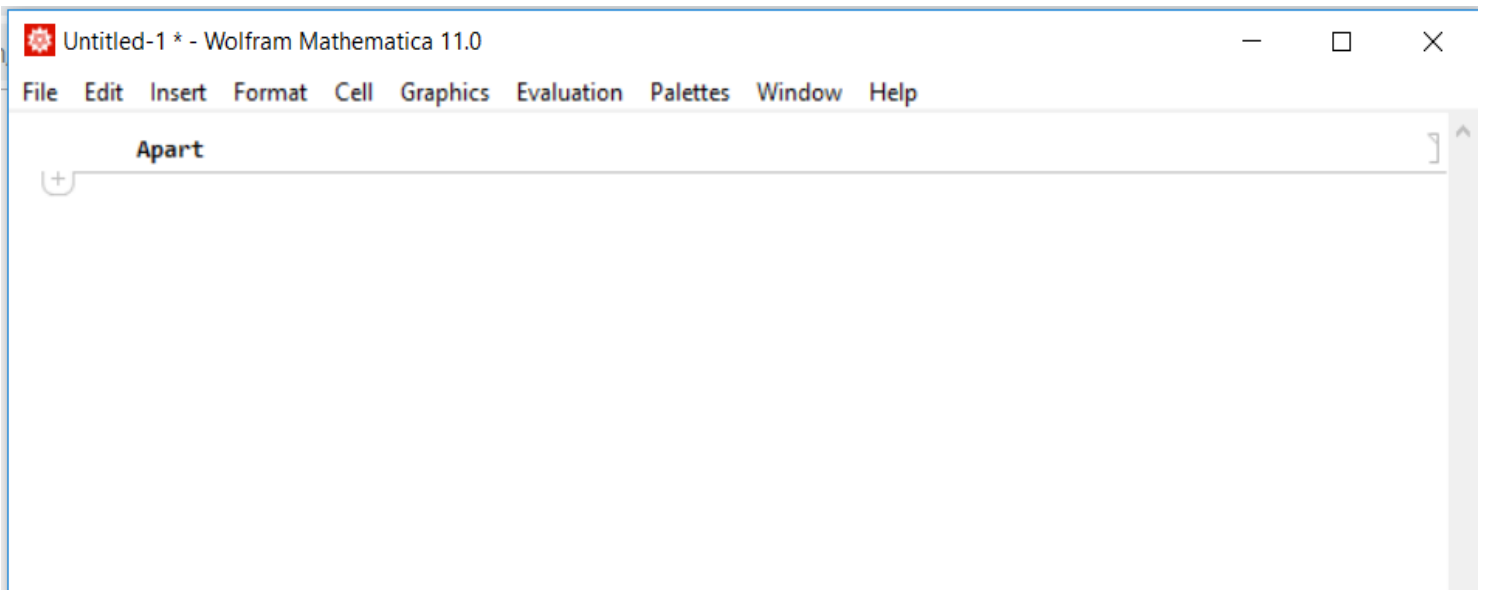

Figure 2. Mathematica software package environment

MATHEMATICA is a software that solves symbolical and numerical problems from different fields of mathematics, physics and other fields of science, technology, finance, medicine, research, education, etc. It is intended to help to solve already known and/or studied problems, as well as researchers who can use it for the most complicated calculations and analyses (Stanimirovic et al., 2002). So far it has been used for practical purposes. Furthermore, it has provided help in solving many theoretical problems. The application of mathematics extends to all fields of science, technology, and business. This software package has great features. MATHEMATICA is especially suitable for the following applications: processing of numerical data,

- the ability of symbolic processing,

- a system for the graphical display of data and functions.

Most of the users of the "MATHEMATICA" package are professionals in the field of engineering. However, it is actively used in education. Hundreds of courses, starting from higher Educational Institutions, such as secondary schools are based on the software package "MATHEMATICA". Also, the use of different versions became an important tool for students at all levels of education. Users of this package are located in all countries, including all ages, all kinds of occupations, i.e. engineers, teachers, artists, composers, linguists, and medical workers.

The WIRIS, together with some additional features, is a tool that is extremely useful for collaborative work in the form of chatting or online conferencing (Saracevic et al. 2012). New software tools can be used by teachers and students. In mathematics teaching these tools can be applied in testing development, with a set of questions or tasks where the teacher is eager to check how much the student has understood the material which is presented during the teaching time. Knowledge testing is one of the most objective tools that enable students to measure knowledge and assess the quality of the education system
(Selimi \& Saracevic, 2017). These types of tests are also known as tests for assessing success because it measures/assesses the information they receive during their education. Tasks in these tests are divided into reproductive and recognition tasks according to the form of their formulation.

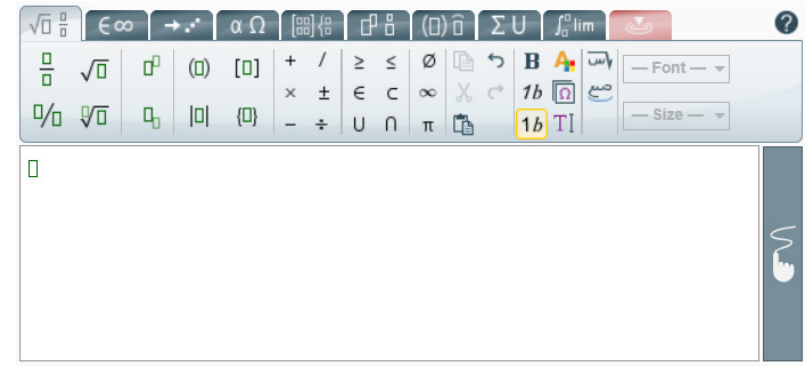

Figure 3. WirisQuiz package environment

\section{Research Methodology}

To collect data and determine the impact of the application of modern technologies in the material handling, identical pre-tests and post-tests are prepared, that is, tests that mainly evaluate re-agency and reproduction of the mathematical facts. Pre-test data was evaluated through relevant procedures and results are processed in terms of both groups. Three months later of learning using interactive applications, both groups were applied post-testing. After posting the post-testing results, a survey was conducted for all students and teachers who are part of the research sample.

\section{Materials}

Two tests were used in the study and they were used for both groups. Tests consisted of different types of tasks. In the first type, the student-constructed and wrote the solution. In this set of tasks there were two types of questions: 
- Recognition type: they examined whether a student was able to find the correct answer;

- Filling type: the student completes the text, it fills the gap in the sentence or more sentences.

In the second type there were tasks in which the students choose with the correct options from the multiple choices, where four types of tasks were most commonly used:

- $\quad$ Type of double choice ("true-false"): students judges whether the claims in the tasks were correct or incorrect;

- Type of multiple choice: the students had to choose the correct answer or option between the multiple solutions offered;

- Type of comparison: here students compared the presented two or three concepts (concepts, events)

- Ordering type: the students arranged the data in the solution according to a certain criterion.

Item questions with double and multiple-choice represent the knowledge that primarily is in the recognition level, while the comparison tasks could examine the understanding of teaching contents, facts, intellectual abilities and ability of applicable knowledge (Strugar, 2006). Each of the types of tasks had its advantages and disadvantages. The presence of a particular type of tasks in a test indicated the activities that are expected from student, which actually speak about the quality of the knowledge, which meant that the knowledge could range from the lowest quality such as recognition (type of double choice, type of multiple-choice), at the higher levels like a reproduction, operational (applicable, applicative) (eg type of affiliation and association) or creative (productive) knowledge (Poljak, 1991).

\section{Procedure for data collection and test score}

The data collection process involves three steps: pre-tests, post-tests, and students'/teachers' survey. The implementation of each step in this research lasted for ten weeks. The pre-testing aimed to identify the possible problems that would arise in the post-testing. The third step analyzed the results obtained from the questionnaires. Each questionnaire was reviewed individually, no revision of the questionnaires was carried out based on the collected data in the evaluation phase, as it was found that there were no questionnaires in which there were illogical answers and an assessment was made to a total of 547 respondents.

\section{Results}

The first procedure in the data analysis process was to calculate the arithmetic mean and standard deviations between pretest and posttest results of the control and experimental group. In each test, a total of 80 points were obtained.

Table 1. Pre-test results

\begin{tabular}{|c|c|c|c|c|c|}
\hline \multicolumn{2}{|c|}{ Group } & $\mathrm{N}$ & Mean & $\begin{array}{c}\text { Std. } \\
\text { Deviation }\end{array}$ & $\begin{array}{c}\text { Std. Error } \\
\text { Mean }\end{array}$ \\
\hline \multirow{2}{*}{$\begin{array}{c}\text { Pretest } \\
\text { results }\end{array}$} & Control group & 263 & 56.26 & 12.368 & .763 \\
\cline { 2 - 6 } & $\begin{array}{c}\text { Experimental } \\
\text { Group }\end{array}$ & 263 & 56.13 & 10.934 & .674 \\
\hline
\end{tabular}

In Table 1 we see that the arithmetic mean and the standard deviation of the result of the pretest for both groups was very close. It followed that the levels of mathematical knowledge for both groups were almost the same. After this step, next, we needed to do was to decide on the next procedure, that would analyze the results of the pretest. To select the appropriate procedure, we considered the distribution of the results for which we could see that was close to a normal distribution. For this reason, we determined the Independent-Samples T-Test as an analysis procedure, because this test represented a convenient procedure for analyzing data with a normal distribution.

Although the arithmetic means and standard deviation from the results of the pretest for both groups were very close, this was not enough for us to ensure that these two groups were comparable. To identify whether the groups were comparable, we applied the Levene Test for Equality of Variances to the obtained results. To this end, we gave the following null and alternative hypotheses for the results of the pretest:

$$
\begin{aligned}
& H_{0}: \sigma_{\text {pre_control }}^{2}=\sigma_{\text {pre_experimental }}^{2} \\
& H_{a}: \sigma_{\text {pre_control }}^{2} \neq \sigma_{\text {pre_experimental }}^{2}
\end{aligned}
$$


These hypotheses were tested at a 0.05 significance level, which means that the results had been at a $95 \%$ confidence interval. If the significance of equality of variance in the pretest results was less than $0.05, \mathrm{H}_{0}$ is rejected, while $\mathrm{H}_{\mathrm{a}}$ is accepted. The results of the Levene Test for Equality of Variances were given in Table 2.

Table 2. Independent-Samples t Test results for pretest

\begin{tabular}{|c|c|c|c|}
\hline \multicolumn{2}{|c|}{} & \multicolumn{2}{|c|}{$\begin{array}{c}\text { Levene's Test for Equality of } \\
\text { Variances }\end{array}$} \\
\cline { 3 - 4 } \multicolumn{2}{|c|}{} & F & Sig. \\
\hline \multirow{2}{*}{$\begin{array}{c}\text { Pretest } \\
\text { results }\end{array}$} & $\begin{array}{c}\text { Equal variances } \\
\text { assumed }\end{array}$ & 1.950 & .163 \\
\cline { 2 - 4 } & $\begin{array}{c}\text { Equal variances not } \\
\text { assumed }\end{array}$ & & \\
\hline
\end{tabular}

From the results in Table 2, it can be seen that the significance level was 0.163 which was greater than 0.05 so that $\mathrm{H}_{0}$ is accepted. In other words, these results were provided by two comparable groups, since the differences in the pretest results of the control and experimental group were the same. Therefore, we conclude that both groups were almost identical in pre-testing. Afterward, these two groups began to receive instruction on interactive tools. The experimental group had internet access and the ability to use interactive applications on a daily basis, while the control group used these tools only once a week at school.

\section{General statistics of posttest results}

Identically as in pretest, we test the performance of both groups with the posttest. Posttest results are given in Table 3.

Table 3. Posttest results

\begin{tabular}{|c|c|c|c|c|c|}
\hline \multicolumn{2}{|c|}{ Group } & N & Mean & $\begin{array}{c}\text { Std. } \\
\text { Deviation }\end{array}$ & $\begin{array}{c}\text { Std. Error } \\
\text { Mean }\end{array}$ \\
\hline \multirow{2}{*}{$\begin{array}{c}\text { Posttest } \\
\text { results }\end{array}$} & Control group & 263 & 61.73 & 11.063 & .682 \\
\cline { 2 - 6 } & $\begin{array}{c}\text { Experimental } \\
\text { Group }\end{array}$ & 263 & 67.49 & 11.916 & .735 \\
\hline
\end{tabular}

Similar to the pretest procedure, the results of the posttest were examined. According to the findings, the results were normally distributed and we applied the Independent-Samples T-Test. In order to find out whether both group's posttest scores were comparable or not, again we applied Levene's Test for Equality of Variances. A null and an alternative hypothesis we gave similarly as in the case of the pre-test.

$$
\begin{aligned}
& H_{0}: \sigma_{\text {post_control }}^{2}=\sigma_{\text {post_experimental }}^{2} \\
& H_{a}: \sigma_{\text {post_control }}^{2} \neq \sigma_{\text {post_experimental }}^{2}
\end{aligned}
$$

The hypotheses were tested at the 0,05 significance level, which meant that the results had been in the $95 \%$ confidence interval. The results of Levene's Test for Equality of Variances for the posttest were given in Table 4.

Table 4. Independent-Samples $t$ Test results for posttest

\begin{tabular}{|c|c|c|c|}
\hline \multicolumn{2}{|c|}{} & \multicolumn{2}{|c|}{$\begin{array}{c}\text { Levene's Test for Equality of } \\
\text { Variances }\end{array}$} \\
\cline { 3 - 4 } & $\mathrm{F}$ & Sig. \\
\hline \multirow{2}{*}{$\begin{array}{c}\text { Posttest } \\
\text { results }\end{array}$} & $\begin{array}{c}\text { Equal variances } \\
\text { assumed }\end{array}$ & .625 & .429 \\
\cline { 2 - 4 } & $\begin{array}{c}\text { Equal variances not } \\
\text { assumed }\end{array}$ & & \\
\hline
\end{tabular}

From the results in Table 4, we see that the significance in the posttest was 0.429 which was greater than 0.05 so that $\mathrm{H}_{0}$ is accepted. This shows that we had two comparable groups in terms of their results after testing because the difference in the results of their tests was the same. Thus, we can conclude that the effectiveness of applying interactive applications for mathematics learning can be used in results measuring in these two groups.

We applied t-Test for Equality of Means to compare the average success for both groups. The results of the tests were given in Table 5 and listed in Table 6.

Table 5. Pre-test results

\begin{tabular}{|c|c|c|c|c|c|c|}
\hline \multicolumn{9}{|c|}{ t-test for Equality of Means } \\
\hline \multirow{2}{*}{$\mathrm{T}$} & $\mathrm{df}$ & Sig. (2-tailed) & Mean Difference & $\begin{array}{c}\text { Std. Error } \\
\text { Difference }\end{array}$ & $\begin{array}{c}\text { 95\% Confidence Interval of the } \\
\text { Difference }\end{array}$ \\
\cline { 5 - 8 } & & .893 & .137 & 1.018 & -1.863 & 2.137 \\
\hline .134 & 524 & .893 & .137 & 1.018 & -1.863 & 2.137 \\
\hline .134 & 516.236 & & & &
\end{tabular}

\begin{tabular}{|c|c|c|c|c|c|c|}
\hline \multicolumn{7}{|c|}{ t-test for Equality of Means } \\
\hline \multirow{2}{*}{$\mathrm{T}$} & \multirow{2}{*}{$\mathrm{df}$} & \multirow{2}{*}{ Sig. (2-tailed) } & \multirow{2}{*}{ Mean Difference } & \multirow{2}{*}{$\begin{array}{l}\text { Std. Error } \\
\text { Difference }\end{array}$} & \multicolumn{2}{|c|}{$\begin{array}{c}95 \% \text { Confidence Interval of } \\
\text { the Difference }\end{array}$} \\
\hline & & & & & Lower & Upper \\
\hline-5.746 & 524 & .002 & -5.760 & 1.003 & -7.730 & -3.791 \\
\hline-5.746 & 521.136 & .002 & -5.760 & 1.003 & -7.730 & -3.791 \\
\hline
\end{tabular}

Table 6. Posttest results 
The null and alternative hypotheses of the average success in pretest and post-test are as follows:

\begin{tabular}{|c|c|}
\hline$H_{0}: \mu_{\text {pre_control }}=\mu_{\text {pre_experimental }}$ & $H_{0}: \mu_{\text {post_control }}=\mu_{\text {post_experimental }}$ \\
$H_{a}: \mu_{\text {pre_control }} \neq \mu_{\text {pre_experimental }}$ & $H_{a}: \mu_{\text {post_control }} \neq \mu_{\text {post_experimental }}$ \\
\hline
\end{tabular}

From Table 5 we see that the significance value was 0.893 which was greater than 0.05 , so $\mathrm{H}_{0}$ was accepted. This result shows that there is no significant difference in the success of the two groups in the pretension and this is indicated with a confidence of $95 \%$. In other words, the experimental and control groups were almost identical before applying interactive applications.

According to the results in Table 6, we see that the value of the meaning was $0.02<0.05$, so in this case, $\mathrm{Ha}$ is accepted. This means that there was a significant difference in the success of the control group and the experimental group in the posttest. Consequently, we conclude that there was sufficient evidence to suggest that interactive tools are more effective in learning mathematics as a discipline. The second objective of this paper is to examine the students' attitudes towards their responsibility for their learning. The learners' autonomy plays an important role in the process of learning mathematics. In this paper, we are particularly interested in how to improve motivation and the ability to learn mathematics independently. According to the results of this study, we should note that the students' motivation for attending online teaching is far greater than the students' who attend only traditional classes. In particular, we can give an example that in the tasks that were an integral part of the activity for each week, student's responses were more complete and much better understood what was being asked to them. The results of the questionnaires were used to find the answer to the following questions in this research. In item questioned as: "Do you prefer classical classes or classes with interactive tools?" 11\% (58) students answered classical and 89\% (468) classes with interactive teaching tools.

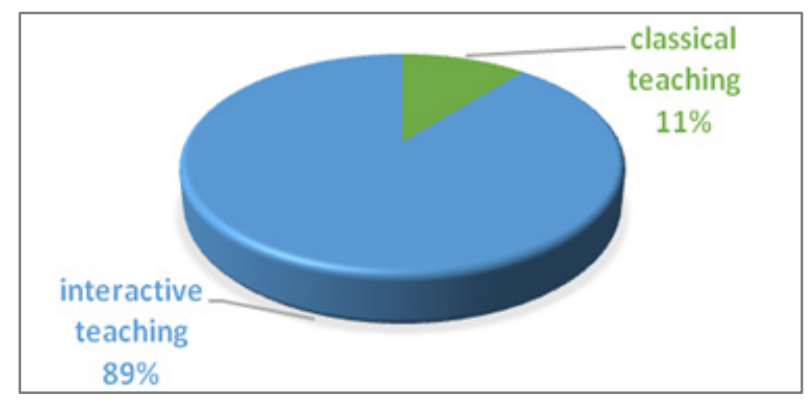

Graph 1. Types of classes

As a reason for that, they stated the following:

- It was very important in geometry learning, animation, and visualization of the problem;

- $\quad$ Some things were better seen and understood; in this way, the problem-solution was quickly found;

- It was more interesting, some things were better understood and easier to remember;

- It was much easier to understand the material in this way, it would be useful to apply in such classes of other subjects, especially in chemistry and physics;

- It was generally more interesting, but the traditional courses could be more interesting, it depended on the teacher;

In item questioned as: "Why do you think you easily learn, understand and solve problems using interactive tools in your classroom and your own work?" Students gave the following answers shown in Graph 2. 


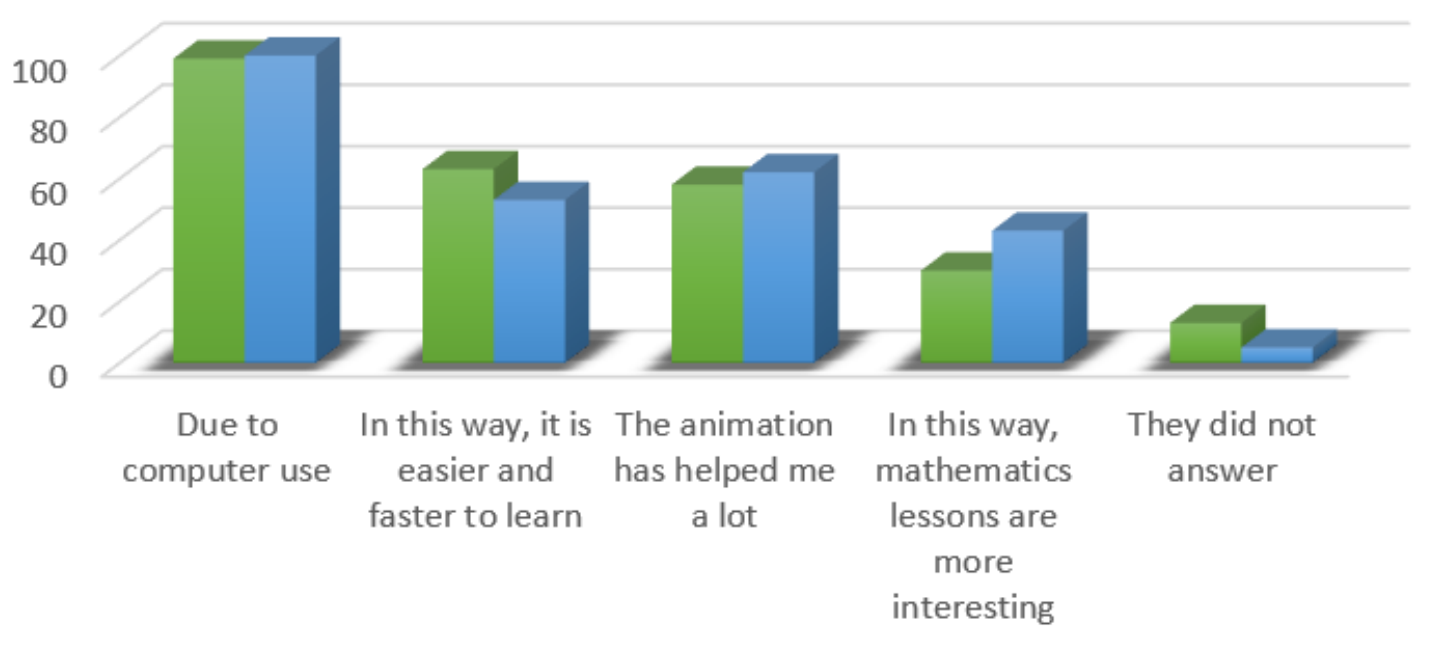

Control group Experimental group

Graph 2. Results about the reasons

The fact is that important obstacles in the learning process with interactive tools were the teachers educated within traditional educational methods. These teachers were not ready for a change in their teaching way. This resistance of teachers has reflected in the sentences "this kind of teaching is not possible" or "I can not do it".

\section{Discussion and Conclusions}

One of the most important findings of our research is that the lessons with digital tools motivate students and decrease the attention problems compared to the lessons with classical methods. The use of digital tools in lessons showed that it had a positive effect on the learning process of students. We detected that the findings match with the results that had been obtained in the findings papers (Holmes, 2009) and (Bokhove \& Drijvers, 2010). As in (Atkinson, 2005) and (Lin, Chen \& Liu, 2017), also the findings of our study showed that digital tools improved the training process. However, the digital tools help students to prepare different types of projects and provide distance education. Thus, we found that success is higher for those students who knew how to use digital tools. Our other findings have shown that with digital tools students gain faster and more applicable information. The fact that animation can be given much more information than classical teaching methods shows that the number of courses taken with digital tools should increase. In other words, the use of digital tools in teaching and has a positive impact on the learning process of students. During our research, some new questions have emerged that need additional research:

- In which classes should we use digital tools?

- In which areas of mathematics are more effective to use digital tools (geometry or algebra)?
- What are the additional steps that should be taken to help students understand the lesson with digital tools?

The second finding discovered in this research is the emotional nature of the students. Because of their unsuccessful experience in the past, some students still willing to stay connected to information coming from teachers. Students who are not accustomed to the freedom and responsibility have difficulties to achieve results in teaching with digital tools.

Since 2002 great efforts have been made in North Macedonia to develop a curriculum that supports teaching with digital tools. Especially some reforms have been realized using the curriculum of the gymnasium and secondary vocational schools. It's common that at secondary schools there are very limited resources such as texts, sequential books, and textbooks. Thus, there is still very low, the number of schools with good conditions for the realization of teaching with digital tools. For these reasons, in many schools, the application of learning with digital tools is very difficult. Schools that do not have digital equipment, we suggest the educational centers to use the mobile version of interactive tools that are available in Android and iPhone smartphones for analyzing the impact of using digital tools.

New trends can be only monitored with good education and teaching. Education influences the development of individual skills of people fulfills the expectations of the community contributes to the development of the culture and civilization of any country. Quality education can be achieved using digital tools, with well-educated teachers who will present their students with modern teaching approaches and needs in this century.

To this end, below we set out several suggestions that can solve the problems that arise in the realization of learning with digital tools at schools. The educational 
environment should be equipped with tools that will enable students to learn specific knowledge according to the characteristics of the subject. Creating an educational environment in which students will be active researchers, examiners. Solving problems using appropriate methods and techniques. Courses should be adapted to the processes of interactive learning. Students should be allowed to learn practical work. Each teacher has to understand that the teacher is the guide in the classroom, not the authority. The democratic structure should be established at school and in the classroom; Students need to learn more about democratic behavior and tolerance. It is necessary to organize additional training for teachers about methods and techniques related to the access to interactive learning in teaching.

For further educational matters, we propose that we should conduct similar studies using digital tools to younger students of different age groups and to apply comparative analysis to/for the results to high school students. However, on the basis of the comparative analysis, also the use of these tools in other subjects can be studied that correlate with mathematics, such as physics, chemistry, and biology.

\section{REFERENCES}

[1] Atkinson R., (2005), Multimedia Learning of Mathematics in R. Mayer, The Cambridge handbook of Multimedia Learning, Cambridge University Press, 393-408.

[2] Bokhove, C., Drijvers, P. (2010). Digital Tools for Algebra Education: Criteria and Evaluation. Int $J$ Comput Math Learning 15, 45-62 https://doi.org/10.1007/s10758-010-91 $62-\mathrm{x}$

[3] Djukic M. (1995.), Individualizacija procesa usvajanja znanja u nastavi, Nastava I vaspitanje, 44(3), 197-206.

[4] Glenda A. (1996), Active Learning in a Constructivist Framework, Educational Studies in Mathematics, 31 (4), 349-369

[5] Holmes, K. (2009). Planning to teach with digital tools: Introducing the interactive whiteboard to pre-service secondary mathematics teachers. Australasian Journal of Educational Technology, 25(3).https://doi.org/10.14742/aje t.1139

[6] Hoyles C., Noss R. (2003) What can digital technologies take from and bring to research in mathematics education? In: Bishop A.J., Clements M.A., Keitel C., Kilpatrick J., Leung F.K.S. (eds) Second International Handbook of Mathematics Education. Springer International Handbooks of Education, vol 10. Springer, Dordrecht https://doi.org/10.12973/eurasia.2017.00744a

[7] Kimberly, R. Boyer. (2002). Using Active Learning Strategies to Motivate Students. Mathematics Teaching In The Middle School, (3), 4-5.

[8] Lin, M., Chen, H., \& Liu, K. (2017). A Study of the Effects of Digital Learning on Learning Motivation and Learning Outcome. Eurasia Journal of Mathematics, Science and Technology Education, 13(7), 3553-3564.

[9] Markus H., \& Hohenwarter J. (2009): GEOGEBRA, zvanično uputstvo 3.2, PMF, Novi Sad.

[10] Mayer, R. E. (2009). Multimedia learning. New York: Cambridge University Press.

[11] Metcalfe, J., \& Shimamura, A. P. (1994). Metacognition: knowing about knowing. Cambridge, MA: MIT Press.

[12] Monaghan J., Trouche L. (2016) Mathematics Teachers and Digital Tools. In: Tools and Mathematics. Mathematics Education Library, vol 110. Springer, Cham

[13] Namestovski Ž. (2008): Uticaj primene savremenih nastavnih sredstava na povećanje efikasnosti nastave u osnovnoj školi, Magistrarski rad, Univerzitet u Novom Sadu, Tehnički fakultet „Mihajlo Pupin”, Zrenjanin.

[14] Niess, M.L. \& Walker, J.M. (2010). Guest Editorial: Digital Videos as Tools for Learning Mathematics. Contemporary Issues in Technology and Teacher Education, 10(1), 100-105. Waynesville, NC USA: Society for Information Technology \& Teacher Education. Retrieved June 20, 2020 from https://www.learntechlib.org/primary/p/34122/.

[15] Piaget, J. (1972). To understand is to invent. New York: The Viking Press. 13

[16] Poljak, V. (1991). Didaktika. Zagreb: Školska knjiga.

[17] Popović N., Naumovic M. (2010): Razvoj interaktivnih simulacija pomoću easy Java simulations i Simulink modela kao eksterne aplikacije, INFOTEH-JAHORINA Vol. 9, Ref. A-4, p. 22-25.

[18] Rao, S.P., \& DiCarlo, S.E. (2001). Active learning of respiratory physiology improves performance on respiratory physiology examinations. Advances in physiology education, 25 1-4, 127-33.

[19] Reynolds W. M., \& Miller G.E., (2003), Handbook of Psychology, Volume 7 Educational Psychology, John Wiley \& Sons, Inc., Hoboken, New Jersey

[20] Saracevic M. (2012), Alati za interaktivnu nastavu matematike i e-učenje, Univerzitet u Novom Pazaru, Srbija

[21] Saracevic M., Milosevic D., \& Masovic S., (2012) Inovacije i napređenje nastave matematike primenom java apleta $\mathrm{u}$ sistemima za e-učenje, Nastava i vaspitanje, 61 (4), 723-740

[22] Selimi A., \& Saracevic M., (2017), Makedonya Cumhuriyetinde devlet matura sinavinda matematik sınavlarının değerlendirilmesi, Hikmet Uluslararası Hakemli İlmi Araştırma Dergisi 30, 88- 101.

[23] Selimi A., Saracevic M., \& Rushiti A. (2018), İnteraktif matematik eğitiminde multimedia cihazların önemi Makedonya örneği, Balkan Educational Studies, 31- 41.

[24] Stanimirovic P.S., \& Milovanovic G.V. (2002), Program Package Mathematica and Applications, Faculty of Electronic Engineering, Niš, (Serbian).

[25] Strugar V. (2006), Tipovizadataka u školskim ispitnim instrumentima i učenikov uspjeh: mogući odgovori na potrebe suvremene škole, Pedagogijska istraživanja, 3 (1), $59-72$. 
[26] Vilotijević M. (1999.), Od tradicionalne ka informacionoj didaktici, Pedagoško društvo Srbije, Beograd.

[27] Weiss, R. E., Knowlton, D. S., \& Morrison, G. R. (2002). Principles for using animation in computer based instruction: Theoretical heuristics for effective design,
Computers in Human Behavior, 18, 465-477.

[28] Woolfolk A., (2016) Educational Psychology, Authorized adaptation from the United States edition, entitled Educational Psychology, 13th edition, by Anita Woolfolk, published by Pearson Education. 